\title{
The Role of CT-Scan inThe Evaluation of Serous Otitis Media
}

\author{
Omar Ramadan* \\ Department of ENT, USA
}

Submission: February 23, 2017; Published: March 01, 2017

*Corresponding author: Omar Ramadan, Independent researcher, ENT registrar, Paterson NJ, USA

\begin{abstract}
Chronic serous otitis media is one of the most common diseasesin the routine practiceof ENT doctors. The most common causes of SOM are related to Eustachian tube dysfunction due to viral or bacterial rhinitis andless commonlydue to nasopharyngeal tumors. CT-scan is not considered in the routine primary evaluation of SOM, but it may be necessary to be done in special cases like nasopharyngeal, nasal, parapharyngeal and malformation lesions. In this article we report a series of five patientscomplaining of serous otitis media that CT-Scan was done in order to appropriate management.
\end{abstract}

Keywords: Serous Otitis Media; CT-Scan; CSF leak; Unilateral Choanel Stenosis, High Jugular Bulb; External Auditory Canal Hump; ParaPharyngeal Tumor

\section{Introduction}

SOM is defined as the accumulation of fluid in the middle ear cavitywithout signs or symptoms of acute ear infection. It is a common problem in the regular practice of ENT physicians. Each year, More than 2 million cases of SOM are diagnosed in the United States and about $50 \%$ to $90 \%$ of childrenfewer than five yearshad at least one episode of SOM. SOM is the most common cause of hearing impairment in children, and it is may lead speech difficulties, attention disturbances, and limited vocabulary. The common causes of SOM include dysfunction of the eustachian tube due to viral or bacterial rhinitis and nasopha- ryngeal tumors. Although CT-Scan has a major role in management of ear diseases, but it has only a limited role in the evaluation of SOM. In this article we are focusing about the importance of CTscan in the management of this entity, we reported five cases of SOM that you may need to obtain CT-scan for the appropriate management [1].

\section{Material and Methods}

\section{Case 1}

22-year-old male had a 10-months history of progressive pain and hearing loss on the left ear, he also complained of a mild difficulty in opening his mouth. Physical examination revealed retracted TM with obvious air-liquid level; he also had slight fullness of the left submucosal tonsil-pharyngeal mass. Computed tomography (CT) and magnetic resonance imaging (MRI) showed an enhanced well circumscribed mass in the parapharyngeal space.

\section{Case 2}

36-year-old man came to our ENT clinic complaining of hearing loss in his right ear which had started 2 months earlier. He had a history of fall from height. Physical examination revealed fluid in the right middle ear without any signs of nasal or nasopharyngeal obstruction. His audiologiacl assessment revealed a mild hearing loss. Right temporal bone CT-Scan demonstrated abony defect in tegmen tympani witha soft tissue density in the right epitympanic recess without ossicular or scutum erosion.

\section{Case 3}

7-year-old girl presented with a history of recurrent right serous otitis media. She also had a history of adenoidectomy and right ear myringotomy with ventilation tubes insertion. The right nostril was partially blocked, which was confirmed by holding a cold steel tongue depressor under her nose and asking her to breathe only through her nose. Nasal endoscopy showed a partial blockage at the level of the right choana with mucus on the floor of the nose. The diagnosis was confirmed by a computed tomography scan

\section{Case 4}

6-year-old girl visited our ENT clinic with earache and hearing loss inher right ear that started 3 months earlier. Physical examination revealed a prominent bony hump in posterior external auditory canal (exostoses) that precluded full TM examination; TM was dull, retracted and congested. She 
had a Type B tympangram. She also reported one episode of ear discharge that treated with oral antibioticsone month before. We could not assess the posterior and superior area of tympanic membrane. Right temporal CT-Scan was obtained to rule out any attic or posterior superiorcholesteatoma ( no cholesteatoma was observed).

\section{Case 5}

A 7 -year-old female had a 3 months history of dull pain and hearing loss in her left ear. Physical examination revealed dull retracted TM and a no-pulsatile bluish discoloration inthe lower portion of the left tympanic membrane, an audiogram revealed a mild conductive hearing loss in the left ear. Left temporal CTScan revealed the presence of high jugular bulb.

\section{Disscusion}

The Majority of the Para-pharyngeal space tumors are benign and most of them are of salivary gland origin. The other types of Para-pharyngeal masses include neurogenic tumors, chemodectomas, lipomas, branchial cysts and lymph node metastasis. Most of these masses are asymptomatic and present as oro-pharyngeal bulge only after attaining a size of $3 \mathrm{~cm}$. Other presenting featuresare pressure symptoms like obstructive dysphagia, airway obstruction and sleep apnea. Otologic symptoms are due Eustachian tube obstruction causing serous otitis media [2,3]. In our case, patient refused to have surgery or further management.

Diagnosis of CSF otorrhea is difficult and need a highindex of suspicion. Physicalexamination should focus on detection or elicitation of CSFotorrhea or rhinorrhea. Otorrhea occurs only when the tympanic membrane is ruptured. In a case of intact tympanic membrane, a pulsatile effusionmay be observed. Valsalva maneuver and positional change may induce or increase CSF leak. We should consider temporal bone CSF leak when meningitis or head trauma occur inassociation with a middle ear serous effusion. If a CSF fluid sample can be obtained,then identification of B2 transferrin by protein electrophoresis can confirm the presence of CSF leak. High-resolution CT- Scan is used to identify the site of the CSF leak and bony anatomy. A bony tegmen tympani defect that associates with an epitympanic soft tissue density and a normal tympanic membrane and ossicular chain suggests herniated intracranial tissue. The surgical management of the temporal bone CSF is based upon defect location and patients the residual hearing ability of the patients [4]. In our case, patient was transferred to neurosurgery unit where he had a middle fossa approach to manage his CSF leak.

Choanalatresiais a congenital obstruction of the posteriornose due to persistence of the buccopharyngealmembrane. It could be bony or membranous, unilateral or bilateral, sporadic or syndromic. It may be associated with multiple ear problems like SOM, ossicular malformation, external ear malformation and sensor-neural hearing loss. So tympanic membrane examination and audiological assessment is advised in all choanal atresia patients [5-7]. In our case, patient father refused surgery for his daughter.

Exostoses are a bony benign growth that orginates from periosteum. They are multiple, bilateral, sessile and broad based lesions, they are located medial to the sutures on the tympanic bone. These are thought to be a reactive condition secondary to multiple cold water immersions, or recurrent otitis externa. Exostoses are usually asymptomatic, unless it has a large size or there are multiple exostoses in the ear canal. The common symptoms of exostoses are conductive hearing loss, otitis externa, otorrhea and otalgia. Total obstruction can lead tocomplications like acquired cholesteatoma. On CT scan, exostoses appear as broad based lesion with no deep extension [8] in our cases, patient responded well to the medical treatment.

In 1914, Page was the first doctor who reported massive hemorrhage during myringotomy in a 10-month old

Boy. In modern Practice, high jugular bulbs can be easily diagnosed through tympanic membraneusing microscope, so we can take care during ear surgery. In suspected cases, CT-Scan has a helpful role in the definite diagnosis of this entity [8]. In our case, we did a myringtomy in the superior anterior area of tympanic membrane to be avoid damaging high jugular bulb.

\section{Conclusion}

We should consider CT - Scan as an option for SOM evaluation in the following cases:

a) Nasal obstruction disesases like choanal polyps, Nasal polyps, choanal atresia, anddeviated nasal septum.

b) Nasopharyngeal masses.

c) Para-pharyngeal masses.

d) Malformation of external auditory canal.

e) High jugular bulb.

f) Patients with history of head trauma or meningitis.

\section{References}

1. Lambert M (2016) AAO-HNS Releases Updated Guideline on Management of Otitis Media with Effusion. Am Fam Physician 94(9): 747-749.

2. Batsakls JG, Snelge N (1989) Parapharyngeal and Retropharyngeal Space diseases. Annals of Otorhmolaryngology 98(4 Pt 1): 320-321.

3. Ricardo L, Carrau MD, Eugene N, Myers MD, Jonas T, et al. (1990) Management of Parapharyngeal space Tumor. Laryagoscope 583-589.

4. Pappas DG, Hoffman RA, Holliday RA, Hammerschlag PE, Pappas DG, et al. (1995) Evaluation and management of spontaneous temporal bone cerebrospinal fluid leaks. Skull Base Surg 5(1): 1-7.

5. Booth AP, Drake-Lee AB (1991) Unilateral choanal atresia. Journal of the Royal Society of Medicine. 84(10): 622.

6. Blake KD, Russell-Eggitt IM, Morgan DW, Ratcliffe JM, Wyse RK (1990) Who's in CHARGE? Multidisciplinary management of patients with CHARGE association. Archives of Disease in Childhood 65(2): 217-223. 
7. Kemink JL, Graham MD (1982) Osteomas and exostoses of the external auditory canal - medical and surgical management. J Otolaryngol (2): 101-106.

8. Kondoh K, Kitahara T, Mishiro Y, Okumura S, Kubo T (2004) Management of hemorrhagic high jugular bulb with adhesive otitis media in an only hearing ear: transcatheter endovascular embolization using detachable coils. Ann OtolRhinolLaryngol 113(12): 975-979.

Your next submission with Juniper Publishers will reach you the below assets

- Quality Editorial service

- Swift Peer Review

- Reprints availability

- E-prints Service

- Manuscript Podcast for convenient understanding

- Global attainment for your research

- Manuscript accessibility in different formats ( Pdf, E-pub, Full Text, Audio)

- Unceasing customer service

Track the below URL for one-step submission https://juniperpublishers.com/online-submission.php 